\title{
Journal of Islamic Economics and Finance Studies
}

\section{Pengaruh Islamic Branding dan Product Ingredients Terhadap Minat Beli Produk PT HNI HPAI Kota Bengkulu}

\author{
Nonie Afrianty \\ Institut Agama Islam Negeri (IAIN) Bengkulu \\ noni@iainbengkulu.ac.id \\ Detri Agustina \\ Institut Agama Islam Negeri (IAIN) Bengkulu \\ detriagustina@gmail.com
}

Received: September 14, 2020 | Accepted: November 22, 2020 | Published: November 25, 2020

\begin{abstract}
Indonesia is the largest adherent of Islam in Southeast Asia. This has attracted producers to create Islamic branding as an attraction for consumers to buy. Muslim consumers are required to be selective in choosing products to consume. Halal label on product packaging does not necessarily guarantee the halal product. Some people do not see the product ingredients in buying consumer products tend to follow the Trand and the properties obtained from these products. This study aims to determine the effect of Islamic Branding and Product Ingredients Against Interest in Buying HNI-HPAI Products in Bengkulu City, the population that is the object of this research is the Consumer of HNI-HPAI Products at Al-Fatih Business Center II HPAI Bengkulu City, The samples used are as many as 94 people were sampled in this study, using the accidental sampling method. The analytical method used in this study is the multiple regression analysis method with the application of SPSS16. The results of the research are based on partial hypothesis testing (t test) showing that the Islamic Branding and Product Ingredients variables significantly influence buying interest. The results of the F test Islamic branding and product ingredients together have a positive and significant effect on buying interest. This can be seen in the calculated $F$ value of 70.676 and a significant value of $0.000<0.05$. Determination Coefficient Test Results (R2) obtained Rsquer of 0.608. This shows that the dependent variable of buying interest can be explained by the Islamic Branding and Product Independent variables at $60.8 \%$ while $39.2 \%$ is explained by other factors outside the studied variables.
\end{abstract}

Keywords: Islamic Branding; Product Ingredients; Buying Interest

\begin{abstract}
Abstrak
Indonesia merupakan penganut agama Islam terbesar di Asia Tenggara. Hal ini menarik produsen untuk menciptakan Islamic branding sebagai daya tarik minat beli konsumen. Konsumen muslim dituntut selektif dalam memilih produk untuk dikonsumsi. Label halal pada kemasan produk belum tentu menjamin kehalalan produk, sebagian orang tidak melihat bahan produk dalam membeli produk cenderung mengikuti trand dan khasiat yang didapat dari produk tersebut. Penelitian ini bertujuan untuk mengetahui pengaruh Islamic Branding Dan Product Ingredients Terhadap Minat Beli Produk HNI-HPAI Di Kota Bengkulu, populasi yang menjadi objek dalam penelitian ini adalah Konsumen Produk HNI-HPAI pada Al-Fatih Business Center II HPAI Kota Bengkulu, Sampel yang digunakan sebanyak 94 orang pengambilan sampel pada penelitian ini, menggunakan metode accidental
\end{abstract}


sampling. Metode analisis yang digunakan dalam penelitian ini adalah metode analisis regresi berganda dengan aplikasi SPSS16. Hasil penelitian berdasarkan uji hipotesis secara parsial (uji t) menunjukan bahwa variabel Islamic Branding dan Product Ingredients secara signifikan berpengaruh terhadap minat beli. Hasil uju F Islamic branding dan product ingredients secara bersama-sama berpengaruh positif dan signifikan terhadap minat beli. Hal ini dapat dilihat pada nilai $F_{\text {hitung, sebesar }}$ 70,676 dan nilai signifikan 0,000 $<0,05$. Hasil Uji Koefisien Determinasi $\left(R^{2}\right)$ diperoleh Rsquer sebesar 0,608 . Hal ini menunjukkan bahwa Variabel dependen minat beli dapat dijelaskan oleh variabel Independen Islamic Branding dan Product sebesar 60,8\% sedangkan 39,2\% dijelaskan oleh faktorfaktor lain diluar variabel yang diteliti.

Kata kunci: Islamic Branding, Product Ingredients, Minat Beli

\section{PENDAHULUAN}

Konsumsi diartikan sebagai penggunaan barang dan jasa untuk memuaskan kebutuhan manusiawi (the use of goods and service in the satisfaction of human wans). Konsumsi adalah suatu kegiatan yang bertujuan untuk menghabiskan daya guna suatu benda, baik yang berupa barang maupun jasa, untuk memenuhi kebutuhan dan kepuasan secara langsung(Ariani, 2014). Islam dalam ajarannya memerintahkan umat untuk selalu mengkonsumsi produk yang baik dan halal sesuai dengan syariat Islam, baik itu dari segi makanan, maupun barang dan jasa(Sukardi, 2015). Hal ini telah termaktub dalam Al-Qur'an, seperti pada Al-Qur'an surat AlBaqarah ayat 168.

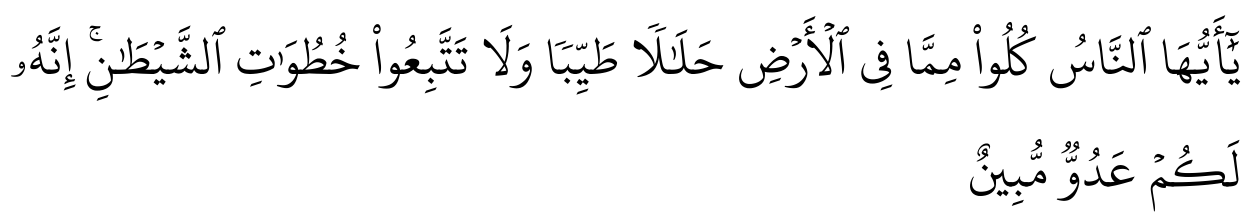

"Hai sekalian manusia, makanlah yang halal lagi baik dari apa yang terdapat di bumi, dan janganlah kamu mengikuti langkah-langkah syaitan; karena sesungguhnya syaitan itu adalah musuh yang nyata bagimu." (QS Al Baqarah [2]: 168)

Indonesia merupakan negara dengan mayoritas penduduk beragama Islam terbesar di Asia Tenggara, hal ini dicatat oleh the word facebook central intelligenceagency 2017. Sebesar 87,2\% masyarakat Indonesia memeluk agama Islam(Data penduduk Islam Asia Tenggara, n.d.). Dengan populasi penduduk mayoritas muslim, hal itu merupakan pasar potensial yang besar bagi berbagai produsen barang dan jasa.(Ranto, 2013)

Islamic Branding bukanlah sebatas nama, simbol, tulisan atau perpaduan dari kesemuanya. Namun, lebih jauh lagi bahwa dalam merek tersebut terkandung prinsip-prinsip syariah yang merupakan perwujudan dari nilai-nilai Islam. Pemunculan merek Islam (Islami) ini didasarkan pada tujuan perusahaan didalam 
mempengaruhi minat beli konsumen, khususnya konsumen muslim. Adanya kesadaran menggunakan produk berlabel Islami merupakan salah satu alasan maraknya bermunculan merek-merek bernuansa Islami pada saat ini (Ranto, 2013). Pengaruh Islamic Branding terhadap minat beli dibuktikan oleh Sri Utami menyatakan Islamic branding berpengaruh secara signifikan terhadap minat beli khususnya konsumen muslim (Utami, 2017). Muhammad Nasrulah menambahkan bahwa Islamic branding yang dimaksudkan bukan hanya sekedar brand produknya menggambarkan Islam akan tetapi dilihat juga dari proses produksi atau kegiatan operasional lainnya harus diperhatikan sehingga sesuai dengan nilai-nilai Islami (Nasrullah, 2015). Dengan demikian, selain melihat dari Islamic branding, faktor yang juga mempengaruhi minat beli ialah product ingredients (bahan-bahan produk).

Bahan produk sangat penting bagi masyarakat umum, terutama umat Islam, dan sangat berpengaruh terhadap minat beli. Bahan Produk penting diperhatikan karena kehalalan produk dapat dilihat melalui komposisinya. Kemudahan konsumen mengetahui informasi bahan produk yang menunjukkan kehalalan suatu produk, dapat mempengaruhi minat konsumen untuk membeli. Hal ini dibuktikan oleh penelitian Dea Retno Sufi Fauzia, Edriana Pangestuti dan Aniesa Samira Bafadhal (D. R. S. Fauzia et al., 2019) menyatakan bahwa bahan produk berpengaruh signifikan terhadap minat beli, Arah hubungan yang positif menujukkan bahwa semakin familiar kosumen pada komposisi produk, maka semakin tinggi minatnya untuk membeli produk tersebut.

PT. HNI-HPAl yang kita kenal dengan produk HPAl yang menyediakan produk herbal dan merupakan produk yang mengusung Islamic branding. Produk HPAI adalah salah satu produk mengantongi sertifikat halal dari MUI Pada tanggal $27 \mathrm{Juli}$ 2016 dengan No. SK 002.36.01/DSN-MUI/IV/2015(MUI, 2020), yang memberikan jaminan kebaikan produk. Dan bahan baku yang digunakan untuk produk HPAl tentunya halal dan sesuai dengan syariat Islam. Penjualan produk HNI-HPAl di Indonesia dimulai sejak tahun 2012 dengan cara pemasaran door to door dan awalnya HNI-HPAI hanya menjual dua produk saja kemudian telah berkembang menjadi 80 item hingga sampai saat ini penjualan produk HNI-HPAl sudah tersebar di diberbagai daerah melalui agen dan business center HPAI di Indonesia, hal tersebut membuktikan bahwa, produk HPAI akan menjadi brand produk herbal berlebel halal yang mendapatkan tempat eksklusif di hati para konsumen. Hal ini juga yang menjadikan HNI-HPAI sebagai sarana untuk perbaikan kesejahteraan anggota dan masyarakat. PT HNI-HPAl pernah mendapatkan prestasi sebagai "The Best Trusted Multi Level Company Of The Year" pada tanggal 11 November 2016 (HNI-HPAI, n.d.).

Berdasarkan hasil observasi awal pada beberapa konsumen di Alfatih Business Center II HPAI Kota Bengkulu, beberapa konsumen HPAl tidak melihat komposisi produk dalam membeli produk konsumen cendrung mengikuti trand dan khasiat yang didapatkan dari produk tersebut. Padahal komposisi produk sangat penting 
untuk diketahui sebelum mengkonsumsi suatu produk. Karena konsumen dituntut selektif dalam memilih produk untuk dikonsumsi. Label halal pada bungkus produk belum tentu menjamin kehalalan produk. Hal ini disebutkan dalam penelitian Ali yang menyatakan bahwa baik muslim di Australia maupun di Malaysia terkadang tidak percaya begitu saja terhadap produk yang tersertifikat halal. Mereka akan meneliti lebih lanjut bahan-bahan yang tercantum dalam produk tersebut untuk memastikan bahwa produk tersebut benar-benar halal dan layak konsumsi (Ali, 2012).

Berdasarkan pada uraian di atas maka peneliti tertarik untuk mengetahui pengaruh Islamic branding dan product ingredients terhadap minat beli produk HNIHPAI di Kota Bengkulu dengan objek penelitian Business Center II HPAI Kota Bengkulu.

\section{TINJAUAN PUSTAKA}

\section{A. Minat Beli}

Minat Beli adalah kecenderungan konsumen untuk membeli sesuatu atau mengambil tindakan yang berhubungan dengan membeli dan diukur dengan tingkat kemungkinan konsumen melakukan pembelian(Endah, 2014). Minat beli menurut Kotler dan Keller, "Minat beli merupakan perilaku yang muncul sebagai respon terhadap objek yang menunjukkan keinginan konsumen untuk melakukan pembelian"(Kotler \& Keller, 2009). Ada beberapa faktor utama yang sangat mempengaruhi minat seseorang, antara lain (Rizki \& Yasin, 2014):

1. Pemusatan perhatian, seseorang tidak mungkin dapat menanggapi rangsangan-rangsangan ini, sebagian besar rangsangan akan disaring, menjadi proses yang dinamakan pemusatan perhatian.

2. Keingintahuan, merupakan suatu bentuk rasa ingin mengenal, mengidentifikasi dan memahami apa yang ada disekitarnya. Rasa keingintahuan menyebabkan seseorang akan lebih berminat terhadap sesuatu yang menarik perhatiannya tersebut.

3. Motivasi, yaitu dorongan yang menggerakkan. Pentingnya motivasi karena motivasi adalah hal yang menyebabkan, menyalurkan dan mendukung perilaku manusia.

4. Kebutuhan, persoalan mengenai kebutuhan manusia tidak akan pernah habisnya selama manusia itu hidup di alam ini. Kebutuhan adalah suatu rasa yang timbul secara alami dari dalam diri manusia untuk memenuhi segala sesuatu yang diperlukan dalam kehidupannya

Menurut Kotler kebutuhan yang ada dalam diri manusia dapat diklarifikasikan ke dalam lima kategori dasar, yaitu kebutuhan dasar fiisologis, kebutuhan akan rasa aman, kebutuhan akan cinta dan rasa memiliki, kebutuhan 
akan rasa harga diri dan kebutuhan akan aktualisasi diri (Kotler \& Keller, 2009). Adapun indikator dari minat beli menurut Ferdinand (Faradiba, 2013):

1. Minat transaksional, yaitu kecenderungan seseorang untuk membeli produk

2. Minat refrensial, yaitu kecenderungan seseorang untuk mereferensikan produk kepada orang lain.

3. Minat preferensial, yaitu minat yang menggambarkan perilaku seseorang yang memiliki prefrensi utama pada produk tersebut. Preferensi ini hanya dapat diganti jika terjadi sesuatu dengan produk preferensinya.

4. Minat eksploratif, minat ini menggambarkan perilaku seseorang yang selalu mencari informasi untuk mendukung sifat-sifat positif dari produk tersebut.

\section{B. Islamic Branding}

Islamic branding bertujuan untuk menerapkan empati pada nilai-nilai syariah untuk menarik konsumen muslim dari perilaku dan komunikasi pemasaran yang dilakukan (Ranto, 2013). Praktek Islamic Branding yaitu merek yang sesuai dengan prinsip syariah, yang banyak memunculkan nilai-nilai seperti kejujuran, hormat pada akuntabilitas dan pemahaman inti dengan prinsip-prinsip syariah. Tujuan dari Islamic Branding yang menerapkan empati dengan nilai-nilai syariah adalah dalam rangka untuk menarik konsumen muslim dari perilaku dan komunikasi pemasaran yang dilakukan (Z.A.Jumani \& D, 2012). Islamic branding sebagai bagian dari sebuah produk tidak hanya menggunakan nama Islam sebagai faktor untuk menarik konsumen, tetapi juga dalam hal pemilihan bahan baku, proses produksi dan lainnya harus diperhatikan sehingga masyarakat akan akan terbentuk yang pada akhirnya akan menimbulkan keputusan pembelian(Alserhan, 2010). Pengukuran variabel Islamic Branding diantaranya adalah (Yunus, 2014):

1. Pentingnya merek, yaitu suatu identitas yang mengkomunikasikan suatu janji dari manfaatyang diberikan suatu produk

2. Keakraban merek, yaitu mencerminkan tingkat pengalaman langsung dan tidak langsung konsumen dengan merek

3. Kepercayaan konsumen, yaitu pengetahuan yang dimiliki konsumen tentangsuatu objek, atributnya dan manfaatnya

4. Label Hala, yaitu pemberian tanda halal atau bukti tertulis sebagai jaminan produk yang halal dengan tulisan.

\section{Product Ingredients}

minat pembelian konsumen terhadap makanan sangat terkait dengan faktor individu dan lingkungan seperti informasi pemasaran, situasi dan sifat tertentu yang meliputi bahan-bahan produk (Rezai \& Dkk, 2012). Bahan produk adalah salah satu subjek utama yang paling dikhawatirkan terkait kehalalan (D. R. S. Fauzia et al., 2019). Dalam perspektif islam, bahan makanan terdapat beberapa 
masalah yang perlu dipertimbangkan, termasuk isu-isu dari konsumen pada bahan dan kualitas serta keselamatan dari isi makanan tersebut. Itulah sebabnya pengetahuan tentang bahan-bahan produk makanan sangatlah penting karena hal itu merupakan proses pengambilan keputusan diterima atau ditolaknya sebuah makanan. Sebagian besar konsumen sangat serius untuk mengetahui apa yang mereka konsumsi dan informasi ini umumnya tercantum dalam pelabelan makanan. Pada pelabelan makanan inilah umumnya tercantum komposisi atau bahan-bahan apa saja yang digunakan dalam membuat makanan tersebut. Hal ini juga mempengaruhi perilaku membeli konsumen terhadap produk. Konsumen akan melihat label komposisi sebagai suatu pengetahuan untuk membeli produk atau tidak (Ali, 2012). ada juga kriteria tertentu yang harus dianggap seperti makanan halal juga mencakup aspek keselamatan dan kualitas yang sangat terkait dengan penanganan, pengolahan, peralatan, alat bantu pengolahan, pengemasan, penyimpanan, transportasi, distribusi dan ritel (Ahmad \& Dkk, 2013). Pengukuran variabel komposisi makanan, diantaranya sebagai berikut (Yunus, 2014):

1. Informasi bahan produk, yaitu keteraangan tentang bahan yang digunakan untuk membuat suatu produk

2. Istilah asing, yaitu bahasa yang tidak biasa digunakan oleh masyarakat yang mendiami daerah tertentu

3. Kualitas bahan, yaitu tingkat mutu atau kandungan yang terkandung dalam suatu produk.

\section{Hipotesis}

$\mathrm{H}_{1}$ : Islamic Branding berpengaruh terhadap Minat Beli produk HN-HPAI di Kota Bengkulu

$\mathrm{H}_{2}$ : Product Ingredients berpengaruh terhadap Minat Beli produk HN-HPAl di Kota Bengkulu

$\mathrm{H}_{3}$ : Islamic Branding dan Product Ingredients secara bersama-sama berpengaruh terhadap Minat Beli produk HN-HPAI di Kota Bengkulu.

\section{METODE PENELITIAN}

Jenis penelitian yang digunakan dalam penelitian ini adalah assosiatif, dengan pendekatan kuantitatif. Populasi dalam penelitian ini adalah konsumen produk HNIHPAI (studi pada alfatih business center II HPAI di Kota Bengkulu) yang melakukan pembelian pada Maret tahun 2020 sebanyak 1.395 orang. Dalam menentukan ukuran sampel dari populasi yang akan diteliti, menggunakan rumus slovin sebagai berikut: 


$$
\begin{aligned}
& \mathrm{n}=\frac{N}{1+N\left(e^{2}\right)} \\
& \mathrm{n}=\frac{1.395}{1+\left(1.395(10 \%)^{2}\right)} \\
& \mathrm{n}=\frac{1.395}{1+\left(1.395(0,1)^{2}\right)} \\
& \mathrm{n}=\frac{1.395}{1+13,95} \\
& \mathrm{n}=93,31 \text { dibulatkan menjadi } 94 \\
& \text { Keterangan : } \\
& \mathrm{N} \quad \text { : besaran populasi } \\
& \mathrm{n} \quad: \text { besaran sampel } \\
& \mathrm{e} \quad \text { : nilai keritis (10\%) }
\end{aligned}
$$

Maka berdasarkan hasil diatas sampel yang diambil untuk penelitian ini adalah 94 responden dengan taraf kesalahan $10 \%$. Teknik pengambilan sampel Pada penelitian ini, menggunakan metode accidental sampling. Dimana peneliti memilih Sampel berdasarkan orang yang secara kebetulan ditemui, bila dipandang orang yang kebetulan ditemui itu cocok sebagai sumber data (Sugiyono, 2016).

Sumber dalam penelitian ini diambil dari data primer dan data sekunder. Data primer diperoleh melalui observasi dan kuesioner pada konsumen di Al-Fatih Business Center II HPAI Kota Bengkulu, sedangkan data sekunder diperoleh melalui buku-buku literasi dan penelitian yang relevan.

Teknik pengumpulan data dalam penelitian ini melalui observasi, kuesioner, dokumentasi. Skala yang digunakan dalam kuesioner adalah skala likert. Skala ini digunakan untuk mengukur opini atau presepsi responden mengenai fenomena sosial (Kuncoro, 2013).

Tabel 1. Skala Likert

\begin{tabular}{ll}
\hline Jawaban Sangat Setuju (SS) & Diberi Bobot 5 \\
\hline Jawaban Setuju (S) & Diberi Bobot 4 \\
\hline Jawaban Netral (N) & Diberi Bobot 3 \\
\hline Jawaban Tidak Setuju (T) & Diberi Bobot 2 \\
\hline Jawaban Sangat Tidak Setuju (STS) & Diberi Bobot 1 \\
\hline
\end{tabular}

Dalam langkah mempermudah pengelolaan data penelitian maka peneliti menggunakan aplikasi SPSS 16. Dalam proses tehnik analisis data menggunakan langkah sebagai berikut:

\section{A. Pengujian Kualitas Data}

1. Uji Validitas dan Uji Reliabilitas

Adapun kriteria penilaian uji validitas yaitu:

a. Apabila $r$ hitung $>r$ table (pada taraf signifikasi 0,05 ), maka dapat dinyatakan item kuesioner tersebut valid. 
b. Apabila $r$ hitung $<r$ table (pada taraf signifikasi 0,05 ), maka dapat dinyatakan item kuesioner tersebut tidak valid (Sugiyono, 2016).

Pengujian reliabilitas terhadap seluruh item atau pernyataan dalam penelitian ini akan menggunakan rumus koefisien Cronbach Alpha. Koefisien alpha dapat dikatakan reliabel ketika nilai Cronbach Alpha >0,50 maka dinyatakan reliabele, jika Cronbach Alpha $<0,50$ maka dikatakan tidak reliabel (Juliansyah, 2014).

2. Uji Normalitas dan Homogenitas

Uji normalitas dilakukan dengan cara Uji Kolmogorov Smirnov, yaitu:(Gunawan, 2015)

a. Apabila nilai probabilitas $>0,05$ maka data tersebut dinyatakan berdistribusi normal.

b. Apabila nilai probabilitas $<0,05$ maka data tersebut dinyatakan tidak berdistribusi normal

3. Uji Multikolinearitas

Uji ini digunakan untuk menghitung koefisien kolerasi ganda dan membandingkannya dengan koefisien kolerasi antar variabel bebas serta untuk mengetahui kesalahan standar estimasi model dalam penelitian(Sujarweni, 2015).

1) Apabila nilai VIF $<10$ dan atau nilai Tolerance $>0,1$ maka tidak terdapat masalah multikolinearitas

2) Apabila nilai VIF $>10$ dan atau nilai Tolerance $<0,1$ maka data terdapat masalah multikolinearitas.

B. Pengujian Hipotesis

1. Regresi Linier Berganda

Analisis ini digunakan untuk mengetahui pengaruh tiga atau lebih variabel, yang terdiri dari satu variabel terikat dan dua atau lebih variabel bebas. Untuk dapat mengetahui hal tersebut, peneliti menggunakan rumus sebagai berikut: (Hasan, 2012)

$$
Y=a+b_{1} X_{1}+b_{2} X_{2}+b_{3} X_{3}+e
$$

Keterangan:

Y $\quad$ : variabel terikat

a : konstanta

$b_{1}, b_{2}, b_{3} \quad$ : koefisien regresi

$\mathrm{X}_{1}, \mathrm{X}_{2}, \mathrm{X}_{3} \quad$ : variabel bebas (kualitas produk, harga, promosi)

e : error

2. Uji t-tes

Uji t-tes bertujuan untuk mengetahui pengaruh variabel bebas (secara individu) terhadap variabel terikat. Penerapan pengambilan keputusan adalah sebagai berikut: (Priyanto, 2016) 
a. Apabila $T_{\text {hitung }}>\mathrm{T}_{\text {tabel }}$ dan nilai signifikansi $<0,05$ maka $\mathrm{H}_{0}$ ditolak dan $\mathrm{H}_{\mathrm{a}}$ diterima, maka disimpulkan bahwa variabel bebas berpengaruh terhadap variabel terikat.

b. Apabila $T_{\text {hitung }}<T_{\text {tabel }}$ dan nilai signifikansi $>0,05$ maka $\mathrm{H}_{a}$ ditolak dan $\mathrm{H}_{0}$ diterima, maka disimpulkan bahwa variabel bebas tidak berpengaruh terhadap variabel terikat.

3. Uji F

Uji $\mathrm{F}$ digunakan untuk mengetahui variabel bebas berpengaruh secara bersama-sama terhadap variabel terikat (Priyanto, 2016).

a. Jika nilai $F_{\text {hitung }}>F_{\text {tabel, }}$ signifikansi $<0,05$ maka variabel bebas berpengaruh secara bersama-sama terhadap variabel terikat.

b. Jika nilai $F_{\text {hitung }}<F_{\text {tabel, signifikansi }>0,05}$ maka variabel bebas tidak berpengaruh secara bersama-sama terhadap variabel terikat.

4. Koefisien Determinasi $\left(R^{2}\right)$

Koefisien determinasi terletak pada Model Summary yang ditunjukkan oleh

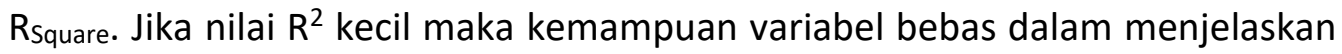
variasi variabel terikat sangat terbatas (Sujarweni, 2015).

Tabel 2. Pedoman Untuk Memberikan Interperstasi Koefisien Determinasi

\begin{tabular}{ll}
\hline Nilai Interval & Skor \\
\hline $0,00-0,199$ & Sangat Rendah \\
$0,20-0,399$ & Rendah \\
$0,40-0,599$ & Sedang \\
$0,60-0,799$ & Kuat \\
$0.80-1,000$ & Sangat Kuat \\
\hline
\end{tabular}




\section{HASIL DAN PEMBAHASAN}

\section{A. Hasil Penelitian}

1. Hasil Pengujian Kualitas Data

a. Uji Validitas dan Reliabilitas

Tabel 3. Hasil Uji Validitas

\begin{tabular}{|c|c|c|c|c|}
\hline variabel & pertanyaan & $\begin{array}{c}\text { Corrected item- } \\
\text { Total Corelation } \\
\left(\mathrm{r}_{\text {hitumg }}\right)\end{array}$ & $\mathbf{r}_{\text {tabel }}$ & Validitas \\
\hline \multirow{4}{*}{$\begin{array}{l}\text { Islamic Branding } \\
\text { (X1) }\end{array}$} & $\mathrm{X} 1.1$ & 0,817 & 0,2028 & Valid \\
\hline & $\mathrm{X} 1.2$ & 0,705 & 0,2028 & Valid \\
\hline & $\mathrm{X} 1.3$ & 0,855 & 0,2028 & Valid \\
\hline & $\mathrm{X} 1.4$ & 0,701 & 0,2028 & Valid \\
\hline \multirow{7}{*}{$\begin{array}{c}\text { Product } \\
\text { Ingredients (X2) }\end{array}$} & $\mathrm{X} 2.1$ & 0.500 & 0,2028 & Valid \\
\hline & $\mathrm{X} 2.2$ & 0,587 & 0,2028 & Valid \\
\hline & $\mathrm{X} 2.3$ & 0,750 & 0,2028 & Valid \\
\hline & $\mathrm{X} 2.4$ & 0,658 & 0,2028 & Valid \\
\hline & $\mathrm{X} 2.5$ & 0,630 & 0,2028 & Valid \\
\hline & $\mathrm{X} 2.6$ & 0,768 & 0,2028 & Valid \\
\hline & $\mathrm{X} 2.7$ & 0,632 & 0,2028 & Valid \\
\hline \multirow{8}{*}{ Minat Beli $(Y)$} & Y.1 & 0,768 & 0,2028 & Valid \\
\hline & Y.2 & 0,787 & 0,2028 & Valid \\
\hline & Y.3 & 0,753 & 0,2028 & Valid \\
\hline & Y.4 & 0,732 & 0,2028 & Valid \\
\hline & Y.5 & 0,760 & 0,2028 & Valid \\
\hline & Y.6 & 0,746 & 0,2028 & Valid \\
\hline & $\mathrm{Y} .7$ & 0,544 & 0,2028 & Valid \\
\hline & Y.8 & 0,756 & 0,2028 & Valid \\
\hline
\end{tabular}

Sumber: data statistik diolah, 2020

Berdasarkan hasil uji pada tabel 3, menunjukkan bahwa semua butir pertanyaan pada variabel Islamic branding, product ingredients dan minat beli dalam kuesioner dinyatakan valid, hal ini karena $r_{\text {hitung }}>r_{\text {tabel }}(0,2028)$ dengan tingkat signifikansi 0,000 $<0,05$.

Setelah pengujian validitas, maka tahap selanjutnya adalah pengujian reliabilitas. Hasil perhitungan uji reliabilitas disajikan pada tabel 4 sebagai berikut:

Tabel 4. Hasil Uji Reliabilitas

\begin{tabular}{|l|l|l|l|}
\hline Variabel & $\begin{array}{l}\text { Cronbach's } \\
\text { Alpha }\end{array}$ & Nilai Keritis & Reliabelitas \\
\hline Islamic Branding (X1) & 0,767 & 0,6 & Reliabel \\
\hline $\begin{array}{l}\text { Product Ingredients } \\
\text { (X2) }\end{array}$ & 0,722 & 0,6 & Reliabel \\
\hline Minat Beli (Y) & 0,871 & 0,6 & Reliabel \\
\hline
\end{tabular}

Sumber: data statistik diolah,2020

Tabel 4 menunjukkan bahwa variabel yang digunakan dalam penelitian ini dinyatakan reliabel, karena masing-masing variabel memiliki nilai Cronbach Alpha $>0,60$. 
b. Uji Normalitas

Tabel 5. Hasil Uji Normalitas

One-Sample Kolmogorov-Smirnov Test

\begin{tabular}{|ll|r|}
\hline & & $\begin{array}{c}\text { Unstandardiz } \\
\text { ed Residual }\end{array}$ \\
\hline $\mathrm{N}$ & Məan & 94 \\
Normal Parameters & a,b & .000000 \\
& Std. Deviation & .76146776 \\
Most Extreme Differences & Absolute & .083 \\
& Positive & .083 \\
& Negative & -.080 \\
Test Statistic & & .083 \\
Asymp. Sig. (2-tailed) & & $.121^{\circ}$ \\
\hline
\end{tabular}

a. Test distribution is Normal

Sumber: data statistik diolah, 2020

Berdasarkan tabel 5 di atas menunjukkan bahwa data yang digunakan dalam penelitian ini terdistribusi normal, karena nilai Asymp. Sig diperoleh nilai sebesar 0,121 >0,05.

c. Uji Multikolenieritas

Tabel 6. Hasil Uji Multikolenieritas

Coefficients ${ }^{\mathrm{a}}$

\begin{tabular}{|c|c|c|c|c|c|c|c|c|}
\hline \multirow[b]{2}{*}{ Model } & & \multicolumn{2}{|c|}{ Unstandardized Coefficients } & \multirow{2}{*}{$\begin{array}{c}\begin{array}{c}\text { Standardized } \\
\text { Coefficients }\end{array} \\
\text { Beta }\end{array}$} & \multirow[b]{2}{*}{$t$} & \multirow[b]{2}{*}{ Siq. } & \multicolumn{2}{|c|}{ Collinearity Statistics } \\
\hline & & B & Std. Error & & & & Tolerance & VIF \\
\hline \multirow[t]{3}{*}{1} & (Constant) & .009 & 3.060 & & .003 & .998 & & \\
\hline & Islamic Branding & 1.277 & .151 & .590 & 8.470 & .000 & .889 & 1.125 \\
\hline & Product Ingredients & .399 & .079 & .350 & 5.036 & .000 & .889 & 1.125 \\
\hline
\end{tabular}

a. Dependent Variable: Minat Beli

Sumber: data statistik diolah, 2020

Dari tabel 6 menunjukkan bahwa data tidak terjadi gejala multikolinearitas antara variabel independen, karena nilai tolerance variabel islamic branding $(0,889)$, product ingredients $(0,889)$ lebih dari 0,10 . Kemudian nilai VIF variabel Islamic Branding (1,125), Product Ingredients $(1,125)$ kurang dari 10 , sehingga model ini dapat digunakan. 
2. Hasil Pengujian Hipotesis

a. Uji Regresi Linier Berganda

Tabel 7. Hasil Uji Regrisi Linier Berganda

Coefficients ${ }^{\mathrm{s}}$

\begin{tabular}{|c|c|c|c|c|c|c|}
\hline \multirow[b]{2}{*}{ Model } & & \multicolumn{2}{|c|}{ Unstandardized Coefficients } & \multirow{2}{*}{$\begin{array}{c}\begin{array}{c}\text { Standardized } \\
\text { Coefficients }\end{array} \\
\text { Beta } \\
\end{array}$} & \multirow[b]{2}{*}{$t$} & \multirow[b]{2}{*}{ Siq. } \\
\hline & & B & Std. Error & & & \\
\hline \multirow[t]{3}{*}{1} & (Constant) & .009 & 3.060 & & .003 & .998 \\
\hline & Islamic Branding & 1.277 & .151 & .590 & 8.470 & .000 \\
\hline & Product Ingredients & .399 & .079 & .350 & 5.036 & .000 \\
\hline
\end{tabular}

a. Dependent Variable: Minat Beli

Sumber: data diolah, 2020

Berdasarkan tabel 7 di atas, maka diperoleh hasil persamaan regresi sebagai berikut:

$$
Y=0,009+1.277 X 1+0,399+e
$$

b. Uji t

Tabel 8. Hasil Uji t

Coefficients ${ }^{\mathrm{s}}$

\begin{tabular}{|c|c|c|c|c|c|c|}
\hline \multirow[b]{2}{*}{ Mode } & & \multicolumn{2}{|c|}{ Unstandardized Coefficients } & \multirow{2}{*}{$\begin{array}{c}\begin{array}{c}\text { Standardized } \\
\text { Coefficients }\end{array} \\
\text { Beta }\end{array}$} & \multirow[b]{2}{*}{$t$} & \multirow[b]{2}{*}{ Sig. } \\
\hline & & $\mathrm{B}$ & Std. Error & & & \\
\hline \multirow[t]{3}{*}{1} & (Constant) & .009 & 3.060 & & .003 & .998 \\
\hline & Islamic Branding & 1.277 & .151 & .590 & 8.470 & .000 \\
\hline & Product Ingredients & .399 & .079 & .350 & 5.036 & .000 \\
\hline
\end{tabular}

a. Dependent Variable: Minat Beli

Sumber: data diolah, 2020

Berdasarkan tabel 8 pada uji t variabel Islamic branding memperoleh nilai $t_{\text {hitung }}(8,470)>t_{\text {tabel }}(1,66177)$ dengan signifikansi sebesar $0,00<0.05$, hal ini menunjukkan bahwa Islamic branding berpengaruh terhadap minat beli produk HN-HPAl di Kota Bengkulu yang artinya $\mathrm{H}_{1}$ diterima $\mathrm{H}_{0}$ ditolak. Sedangkan Hasil uji t variabel product ingredients memperoleh nilai thitung $(5,036)>t_{\text {tabel }}(1,66177)$ dengan signifikansi sebesar $0,00<0.05$, hal ini menunjukkan bahwa product ingredients berpengaruh terhadap minat beli produk HN-HPAl di Kota Bengkulu yang artinya $\mathrm{H}_{2}$ diterima $\mathrm{H}_{0}$ ditolak. 
c. Uji Signifikan Simultan (Uji F)

Tabel 9. Hasil Uji F

ANOVA ${ }^{b}$

\begin{tabular}{|ll|r|r|r|r|r|}
\hline \multicolumn{1}{|c|}{} & \multicolumn{1}{|c|}{$\begin{array}{c}\text { Sum of } \\
\text { Moded }\end{array}$} & \multicolumn{1}{c|}{ Squares } & df & Mean Square & \multicolumn{1}{c|}{$\mathrm{F}$} & Sig. \\
\hline 1 & Regression & 778.206 & 2 & 389.103 & 70.676 & $.000^{=}$ \\
& Residual & 500.996 & 91 & 5.505 & & \\
& Total & 1279.202 & 93 & & & \\
\hline
\end{tabular}

a. Predictors: (Constant), Product Ingredients, Islamic Branding

b. Dependent Variable: Minat Beli

Sumber: data statistik diolah, 2020

Dari tabel 9 diperoleh $F_{\text {hitung }}$ sebesar 70,676 $>F_{\text {tabel }}$ sebesar 3,94 dengan signifikasi $0.000<0,05$, dapat disimpulkan bahwa dari variabel Islamic branding dan product ingredients secara bersama-sama berpengaruh terhadap minat beli produk HNI-HPAI di Kota Bengkulu, yang artinya $\mathrm{H}_{3}$ diterima.

d. Uji Koefisien Determinasi

Tabel 10. Uji Koefisien Determinasi

Model Summary

\begin{tabular}{|l|l|r|r|r|}
\hline $\begin{array}{l}\text { Mode } \\
\perp\end{array}$ & $\mathrm{R}$ & R Square & $\begin{array}{c}\text { Adjusted R } \\
\text { Square }\end{array}$ & $\begin{array}{c}\text { Std. Error of } \\
\text { the Estimate }\end{array}$ \\
\hline 1 & $.780^{=}$ & .608 & .600 & 2.346 \\
\hline
\end{tabular}

a. Predictors: (Constant), Product Ingredients, Islamic Branding

Sumber: data statistik diolah, 2020

Berdasarkan tabel 10 diketahui nilai koefisien determinasi $\left(R^{2}\right)$ menunjukkan bahwa nilai $R^{2}$ sebesar 0,608 atau $60,8 \%$. Hal ini menunjukkan bahwa $60,8 \%$ minat beli dipengaruhi oleh variabel islamic branding dan product ingredients $60,8 \%$ sedangkan 39,2\% dipengaruhi variabel lain diluar penelitian, sehingga dapat disimpulkan bahwa kemampuan variabel bebas (Islamic branding dan product ingredients) dalam menjelaskan variabel terikat (minat beli) adalah kuat.

\section{B. Pembahasan}

1. Pengaruh Islamic Branding terhadap minat beli

Uji hipotesis pertama dilakukan untuk mengetahui pengaruh Islamic branding terhadap minat beli. Hasil uji $\mathrm{t}$ sebagaimana pada tabel 8 menunjukkan bahwa variabel Islamic branding berpengaruh terhadap minat 
beli. Hal ini menunjukkan bahwa konsumen produk HNI-HPAI kota Bengkulu memiliki prioritas terhadap brand pada suatu produk yang akan digunakan. Responden yang merupakan konsumen produk HNI-HPAl kota Bengkulu yang terdiri dari PNS, wiraswasta, karyawan swasta, pelajar/mahasiswa dan lainya yang rata-rata mempunyai pengatahuan atau intelektualitas yang tinggi, sehingga tidak mengherankan jika penggunaan Islamic branding berpengaruh terhadap minat beli mereka pada sebuah produk. Islamic branding sebagai bagian dari sebuah produk tidak hanya menggunakan nama Islam sebagai faktor untuk menarik konsumen, tetapi juga dalam hal pemilihan bahan baku, proses produksi dan lainnya harus diperhatikan sehingga trust masyarakat akan akan terbentuk yang pada akhirnya akan menimbulkan minat beli.

Hasil penelitian ini sejalan dengan penelitian yang dilakukan oleh (Utami, 2017) dan (Nasrullah, 2015) yang menyatakan Islamic branding berpengaruh terhadap minat beli.

2. Pengaruh Product Ingredients Terhadap Minat Beli

Uji hipotesis kedua dilakukan untuk mengetahui pengaruh product ingredients terhadap minat beli. Hasil uji $\mathrm{t}$ sebagaimana pada tabel 8 menunjukkan bahwa product ingredients berpengaruh terhadap minat beli. $\mathrm{Hal}$ ini menunjukan bahwa semakin familiar kosumen pada komposisi produk HNIHPAI, maka semakin tinggi minatnya untuk membeli produk tersebut. Informasi komposisi yang terdapat pada kemasan produk HNI-HPAl tidak asing bagi konsumen dan sudah cukup untuk menilai kehalalan produk HNI-HPAI. Lebih lanjut bahan produk HNI-HPAI dianggap mencerminkan keamanan dan kualitas produk halal.

Hasil penelitian ini sejalan dengan penelitian yang dilakukan oleh ( diah retno sufi Fauzia et al., 2019) yang menyatakan product ingredients atau komposisi produk berpengaruh positif terhadap minat beli konsumen.

3. Pengaruh Islamic Branding dan Product Ingredient terhadap Minat Beli

Uji hipotesis ketiga dilakukan untuk menguji pengaruh Is/amic Branding dan Product Ingredient secara bersama-sama terhadap Minat Beli. Hasil uji $f$ sebagaimana pada tabel 9 menunjukkan bahwa Islamic branding dan product ingredients secara bersama-sama berpengaruh terhadap minat beli.

Dilihat pada tabel 4.15, nilai dari koefisien determinasi (R2) adalah 0,608. Hal ini menjelaskan bahwa variabel-variabel independen kuat dalam menjelaskan variabel dependen sebesar $60,8 \%$. Sebesar $39,2 \% \%$ sisanya menjelaskan variabel lain yang tidak diteliti dalam penelitian ini. Artinya, ketika HNI-HPAI lebih mengenalkan penggunaan Islamic branding dan product ingredients untuk produknya, maka hal tersebut akan meningkatkan minat beli konsumen pada produk HNI-HPAl di Kota Bengkulu. 


\section{SIMPULAN}

Berdasarkan pembahasan, maka dapat disimpulkan bahwa penelian ini menunjukkan variabel Islamic branding berpengaruh terhadap minat beli. Hal ini dapat dilihat pada nilai thitung, sebesar 8,470 dan nilai signifikan 0,000 $<0,05$, dan koefisien regresi mempunyai nilai positif. Selain itu, diketahui pula bahwa variabel product ingredients berpengaruh terhadap minat beli. Hal ini dapat dilihat pada nilai

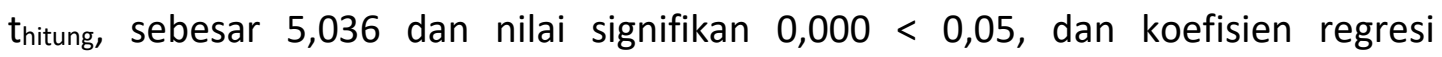
mempunyai nilai positif. Variabel Islamic branding dan product ingredients secara bersama-sama berpengaruh positif dan signifikan terhadap minat beli. Hal ini dapat

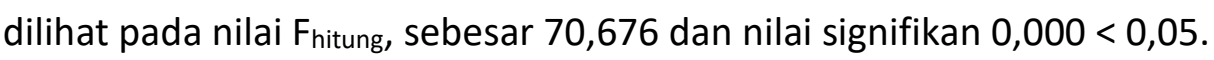

\section{DAFTAR PUSTAKA}

Ahmad, N. A. B., \& Dkk. (2013). A Study on Halal Food Awareness Among Muslim Customers in Klang Valley. 4th International Conference on Business and Economic Research, 1073-1087.

Ali, Y. (2012). Halal Branding. A Study of Moslem Consumers Perspective. On Proceedings of The 2nd Global Islamic Marketing Conference. Abu Dhabi, 1-6.

Alserhan, B. A. (2010). On Islamic Branding: Brands As Good Deeds. Journal of Islamic Marketing, 1(2), 34-49.

Ariani, D. (2014). Analisis Faktor-Faktor yang Mempengaruhi Konsumen di Kabupaten Nagan Raya. Jurnal Ekonomi Dan Kebijakan Publik Indonesia, 1(1), 3.

Data penduduk Islam Asia Tenggara. (n.d.). Retrieved March 10, 2020, from http://data.tempo.co/data/480/indonesia -dengan-muslim-terbesar-di-asiatenggara

Endah, N. H. (2014). Perilaku Pembelian Kosmetik Berlabel Halal oleh Konsumen Indonesia. Jurnal Ekonomi Dan Pembangunan, 22(1), 11-25.

Faradiba, S. R. T. (2013). Analisis pengaruh Kualitas Produk, Harga, Lokasi dan Kualitas Pelayanan Terhadap Minat Beli Ulang Konsumen (Studi Pada Warung "Bebek Gendut). Jurnal Manajemen, 2(3), 2.

Fauzia, diah retno sufi, Pangestu, E., \& Bafadhal, A. S. (2019). Pengaruh religiusitas, sertifikasi halal, bahan produk terhadap minat beli dan keputusan pembelian. Jurnal Administrasi Bisnis (JAB), 66(1), 37-46.

Fauzia, D. R. S., Pangestuti, E., \& Bafadhal, A. S. (2019). Pengaruh Religiusitas, Sertifikasi Halal, Bahan Produk Terhadap Minat Beli Dan Keputusan Pembelian. Jurnal Administrasi Bisnis, 1(66), 27-46.

Gunawan, M. A. (2015). Statistik Penelitian Bidang Pendidikan, Psikologi dan Sosial. Parama Publishing.

Hasan, I. (2012). Pokok-Pokok Materi Statistik 2. PT. Bumi Aksara. 
HNI-HPAI. (n.d.). Penghargaan HNI-HPAI. Retrieved January 27, 2020, from herbalhni-hpai.blogspot.com/2017/02/sertifikat-penghargaan-hni-hpai.html?m=1

Juliansyah. (2014). Analisis Data Penelitian Ekonomi dan Manajemen. PT. Grasindo.

Kotler, P., \& Keller. (2009). Manajemen Pemasaran (13th ed.). Erlangga.

Kuncoro, M. (2013). Metode Riset untuk Bisnis dan Ekonomi. PT.Glora Aksara Pratama.

MUI, D. (2020). Daftar Perusahaan Penjualan Langsung Berjenjang Syariah. https://dsnmui.or.id

Nasrullah, M. (2015). Islamic Branding, Religiusitas dan Keputusan Konsumen Terhadap Produk. Jurnal Hukum Islam, 13(2).

Priyanto, D. (2016). Belajar Alat Analisis Data dan Cara Pengolahannya Dengan SPSS (1st ed.). Gaya Media.

Ranto, D. W. P. (2013). Menciptakan Islamic Branding Sebagai Strategi Menarik Minat Beli Konsumen. JMBA, 1(2), 1.

Rezai, G., \& Dkk. (2012). Assessment of Consumers' Confidence on Halal Labelled Manufactured Food in Malaysia. Social, Science, \& Humanities, 20(1), 33-42.

Rizki, M. F., \& Yasin, H. (2014). Pengaruh Promosi Dan Harga Terhadap Minat Beli Perumahan Obama PT. Nailah Adi Kurnia Sei Mencirim Medan. Jurnal Manajemen Dan Bisnis, 14(2), 135-143.

Sugiyono. (2016). Metode Penelitian Juantitatif Kualitatif R\&D. Alfabeta.

Sujarweni, W. (2015). Metodologi Penelitin Bisnis dan Ekonomi. PT.Pustaka Baru.

Sukardi, D. (2015). Perlindungan Konsumen Terhadap Penggunaan Bahan Kimia Berbahaya Pada Makanan dalam Perspektif Hukum Islam. Al-Mustashfa: Jurnal Penelitian Hukum EKonomi Syariah, 3(1).

Utami, S. (2017). Pengaruh Kualitas Harga dan Islamic Branding Terhadap Minat Beli Produk Kosmetik Halal. Universitas Muhammadiyah Surakarta.

Yunus, N. S. N. M. (2014). Muslim's Purchase Intention towards Non-Muslim's Halal Packaged Food Manufacturer. Procedia -Social and Behavioral Sciences.

Z.A.Jumani, \& D, S. (2012). Bases Of Islamic Branding In Pakistan:Perceptions Or Believes. Interdisciplinary Journal Of Contemporary Research In Business, 3(9), 840-847. 